\title{
Generating a new typology of an urban village
}

\author{
S. S. Zubir ${ }^{1}$, Q. Norhisham ${ }^{1,2} \&$ Y. Rahman ${ }^{2}$ \\ ${ }^{1}$ Center of Studies for Architecture, Faculty of Architecture, \\ Planning and Surveying, Universiti Teknologi MARA, Malaysia \\ ${ }^{2}$ MDRXA Studio, Malaysia
}

\begin{abstract}
The urgent need to rethink the current living conditions in the urban villages of Bandung was established by a desire to regain self-empowerment through creative urban design intervention. Contextual analysis was thoroughly conducted to understand the urban grain of these places. Since the beginning of its establishment, the villages have undergone significant transformations from the basic dwelling spaces to the complex interlocking units of the existing typologies. The proposed pixilated modules are the key in improving the quality of life here as the demand for spaces become a major commodity to population implosion within the city's boundary. This new urban pattern will slowly expand within the existing urban fabric, replacing dilapidated buildings with standard modules, enabling each dwelling to be more affordable. As the community spaces are being shared, this will eliminate unwarranted wastage. Villagers are given essential equipment to construct their own homes, using bamboo as its prime resource material. Since bamboo is endemic to this particular urban environment, if used creatively will prevents flood, erosion, and grows ten times faster than an average timber with the same structural capacity. Growing bamboo itself contributes tremendously to the environment as it recycles $\mathrm{CO}_{2}$ into $\mathrm{O}_{2}$ at an astonishing rate. Many sustainable practices will be integrated in this self-help pixel village community to attain self-sufficiency in their daily lifestyles such as in food production, farming, biogas energy production and a simple rainwater harvesting system. As Bandung is set to be a major tourist destination in Asia, the Pixel Village will be a new brand of indigenous living symbolizing an era of uniqueness and rarity through reformation of the public realm and private domains of the city. As the Pixel Village matures, the dwellers will attain selfsufficiency through shared community spirit and aspirations.

Keywords: self-empowerment, slum rejuvenation, structural efficiency, urban fabric, sustainable and economical urban development.
\end{abstract}




\section{Introduction: site}

The site is separated by the Cikapundung River which divides Bandung into an East and West province. The community within the site are of Nyengseret in the district of Astanaanyar, Bandung [1]. This area is the largest slum village nearest to the heart of Bandung. The Sasak Gantung Bridge is the only means of excess connecting both river banks together within a one kilometer radius. The majority of the villagers are Muslim families, thus conducting regular community activities in two small Mosques within the perimeter of the site. The main dwelling typologies found within the area are mostly of single, double, quadruple and cluster houses.

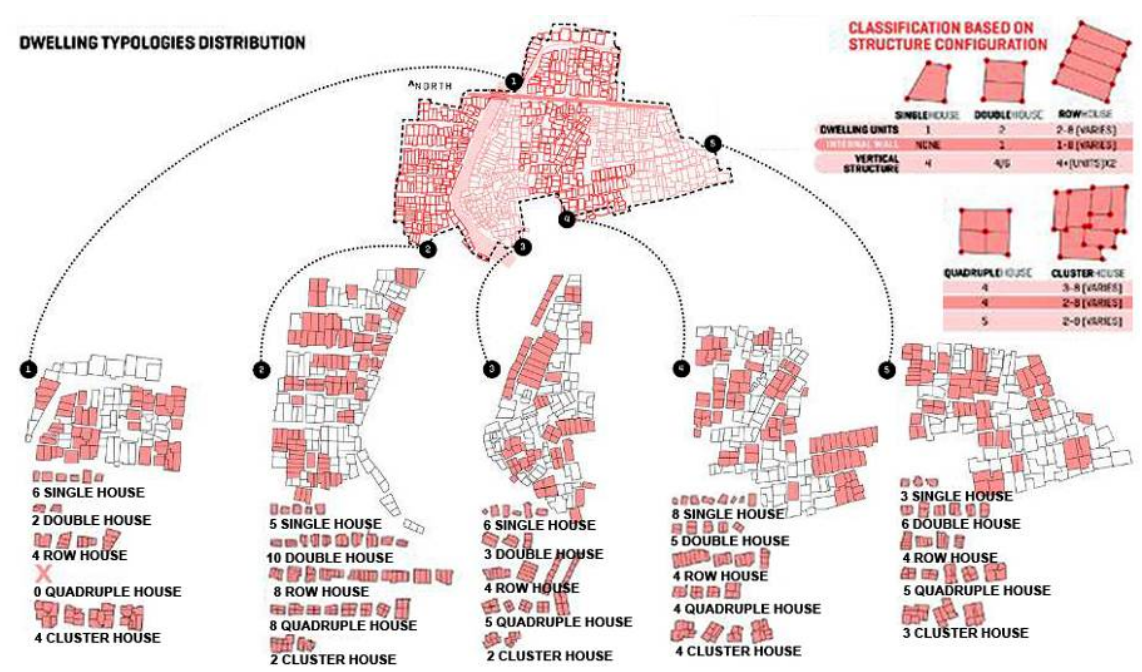

Figure 1: Dwelling typology distribution.

\section{Issues}

Slums are the products of failed policies, bad governance, corruption, inappropriate regulation, dysfunctional land markets, unresponsive financial systems, and a fundamental lack of political will. Each of these failures adds toll on people already deeply burdened by poverty and constrains the enormous opportunity for human development that urban life offers. Today, 1 in 6 of the world population lives in slums. It will increase to 1 in 4 in 2030 and 1 in 3 by 2050 [2]. These villagers live in dense neighbourhoods, lacking legal title to their land, education, clean water and health care facilities. This issue will worsen as the population is rapidly growing, the city does not have enough resources and infrastructure to cater the future generation in masses [3]. There is an urgent need now to rethink the current living condition in the slums in order to design a new typology that supports future growth of the population. Since problems are local, solutions have to be local. 


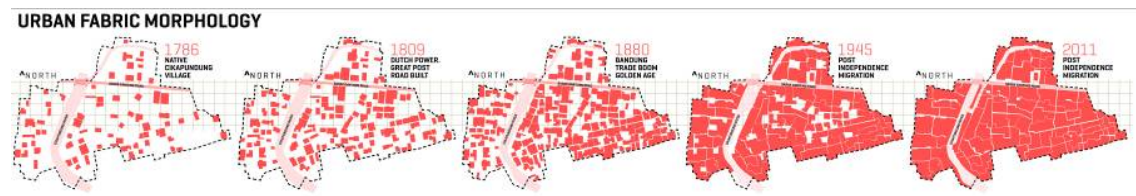

Figure 2: Urban fabric morphology.

\section{Hypothesis}

Self-empowerment is fostered from every aspect to regain their right of power towards their lifestyle, their community and their financial security. The need to redefine tourism brings a bigger meaning to a much wider range of people in Bandung. The urgent need to rethink the current living condition in these slums resulted in a new typology that supports future growth of the population.

These people lack legal title to their land, yet many have the initiative to improve their dwellings, often just one brick at a time [4]. This scenario enables the villagers to fully participate in the design process and will be involved hands on in the construction of their new homes.

There will always be a need for big investments, but now they need to be complemented by programs that match Indonesia's political democracy with economic resources that would allow a more diverse range of local groups to work efficiently as partners using their own organizational resources, skills and aptitudes (urban agglomeration). Due to the cheap labor, small huts within the village are used as a mini factory to produce goods in masses such as textiles, toys and food produce.
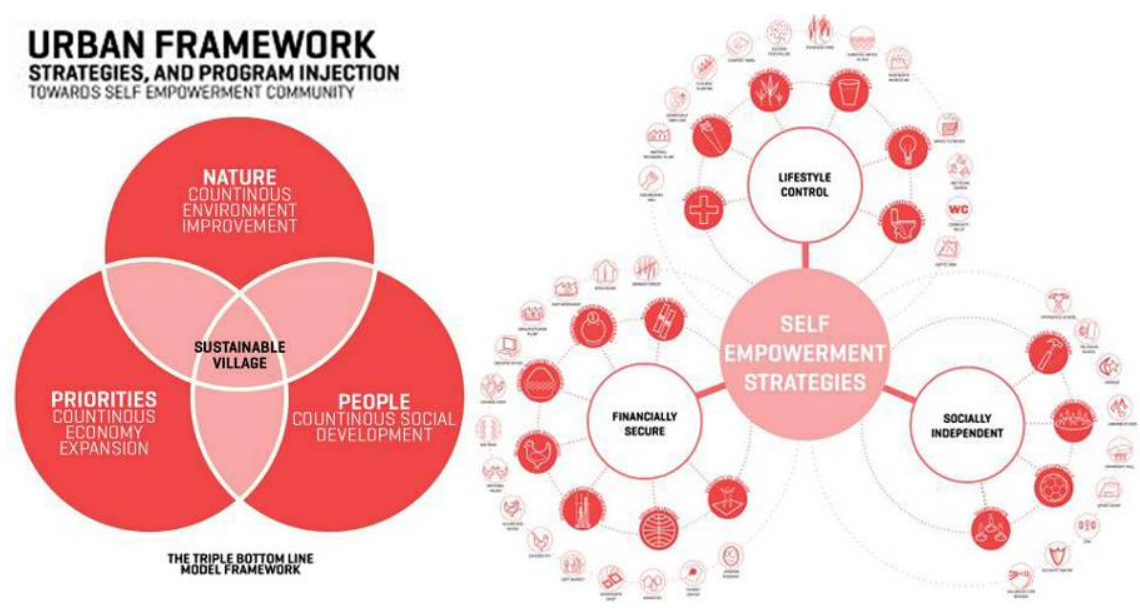

Figure 3: Urban framework strategy. 
These invisible people live in a world where they themselves are seen as a liability to the city. They rely on a bigger power or source to define a future for them as they themselves feel too small to have a say and are not economically capable of a decision that can bring them to become the best they possibly can.

The theme of the project is to help them regain their pride through selfempowerment within the society. The intervention will allow the people to fend for themselves and lead a life to be economically capable, and socially ready for challenges of the future.

\section{Urban morphology}

The current condition of the typical urban dwellings in Bandung's urban village is formed from the basis of square geometries [5]. These geometries can be formed individually, combined, or clustered together. But due to limitation of resources, planning and limited land to build, the dwelling is built in irregular squares that are supported independently from neighbouring dwellings. The formation of a typical village in Bandung according to Siregar [1], is illustrated in Figure 4, whereby these urban villages used to be a small 'kampung' with a low density of residents serving the main perimeter block. The transformation of these urban dwellings worsens as space becomes scarce with the rising populace.

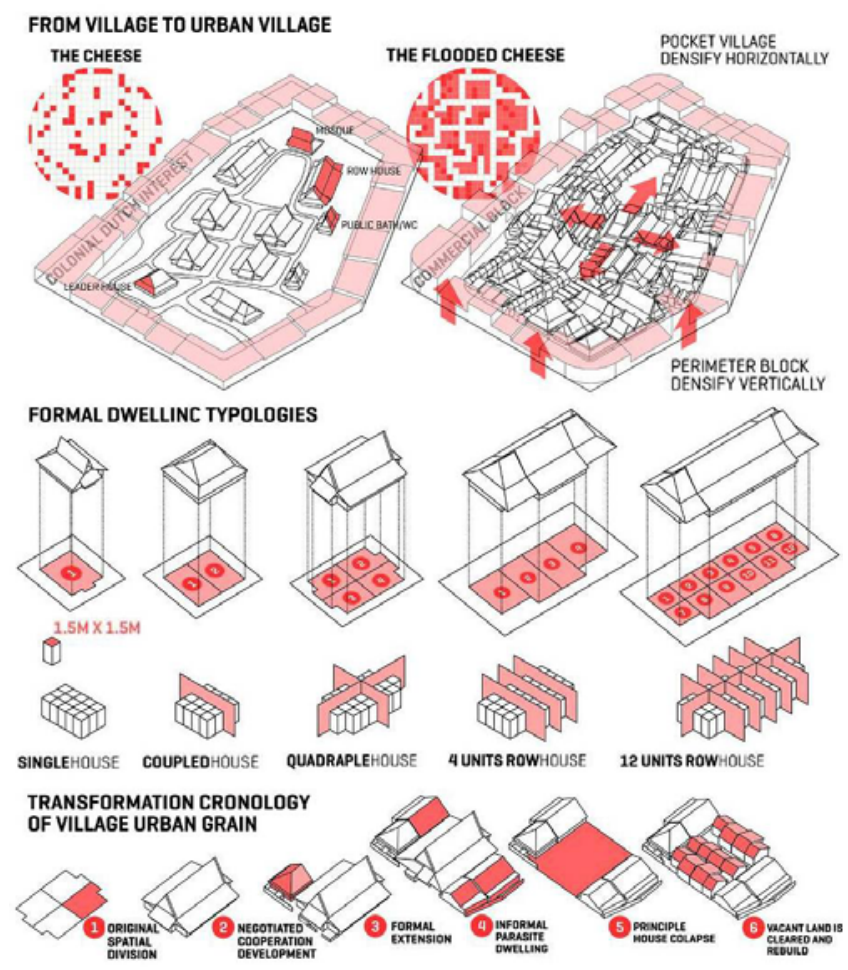

Figure 4: Urban morphology. 
This widespread scenario results in wastage of structural member potential. The new proposal will harness the full potential of saving by sharing structural component to house multiple dwellings. This saving will allow the money to be used for better structural quality dwellings and that incorporate expansion potential.

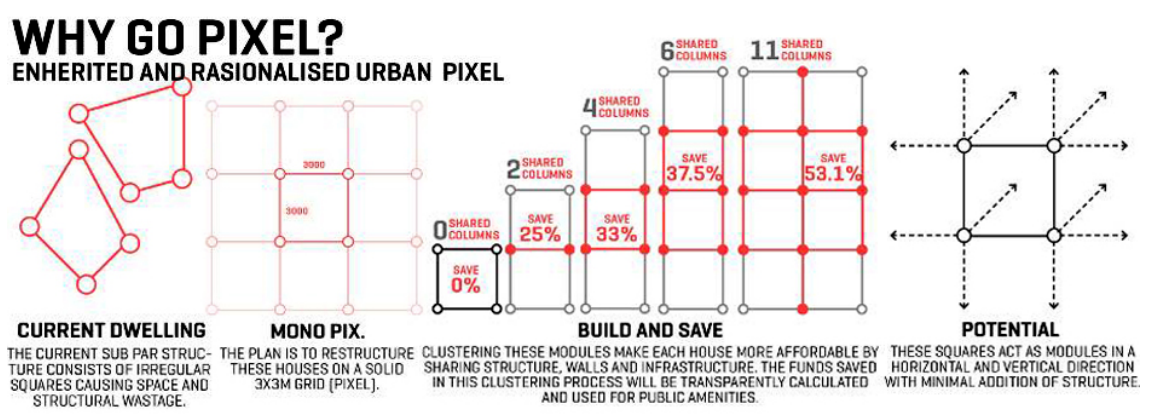

Figure 5: Pixel parameters.

The new formalized (but not necessarily restrictive) grid will help the resident to build new sustainable future dwellings with less cost and with higher spatial efficiency. The new dwelling system will not only expand horizontally, but has the capabilities to grow vertically to accommodate the increasing number of residents that live within the urban village.

Figure 6 graphically explains how the new system will be gradually implemented within the existing urban fabric while they are still in place. The new system will start one storey above the existing village fabric. The elevated house is a countermeasure due to constant and consistent flooding incidents at the banks of Cikapundung River that cause heavy loses to the villagers [6].

In order to increase sanitary quality among residents, new toilet blocks are built fitted with septic tanks and extended piping connections that can be connected to a biogas digester later in the development. These toilet blocks will not only serve the existing residents, but it will eventually be built upward as more new dwellings need to be built on other elevated levels. Additional elevated platforms may be required to link all the houses to these centralized toilet blocks.

Eventually as the old dwellings slowly collapse (due to subpar structure/ flooding), the new dwelling that will house the victim will be built on the new system with future expansion on both horizontal and vertical direction of the elevated platform. These transformations will be influenced by the supply of bamboo and the needs of new dwellings. The new system is not meant for a forced and brutal intervention but rather a gradual and voluntarily effort. The houses will be built together by the community and after the land is released from the old dwelling type, there will be more ground space for bamboo farming, open public spaces and waste management systems can be installed and embedded in the ground, creating a better living environment and provide social development with newly establish public space. 

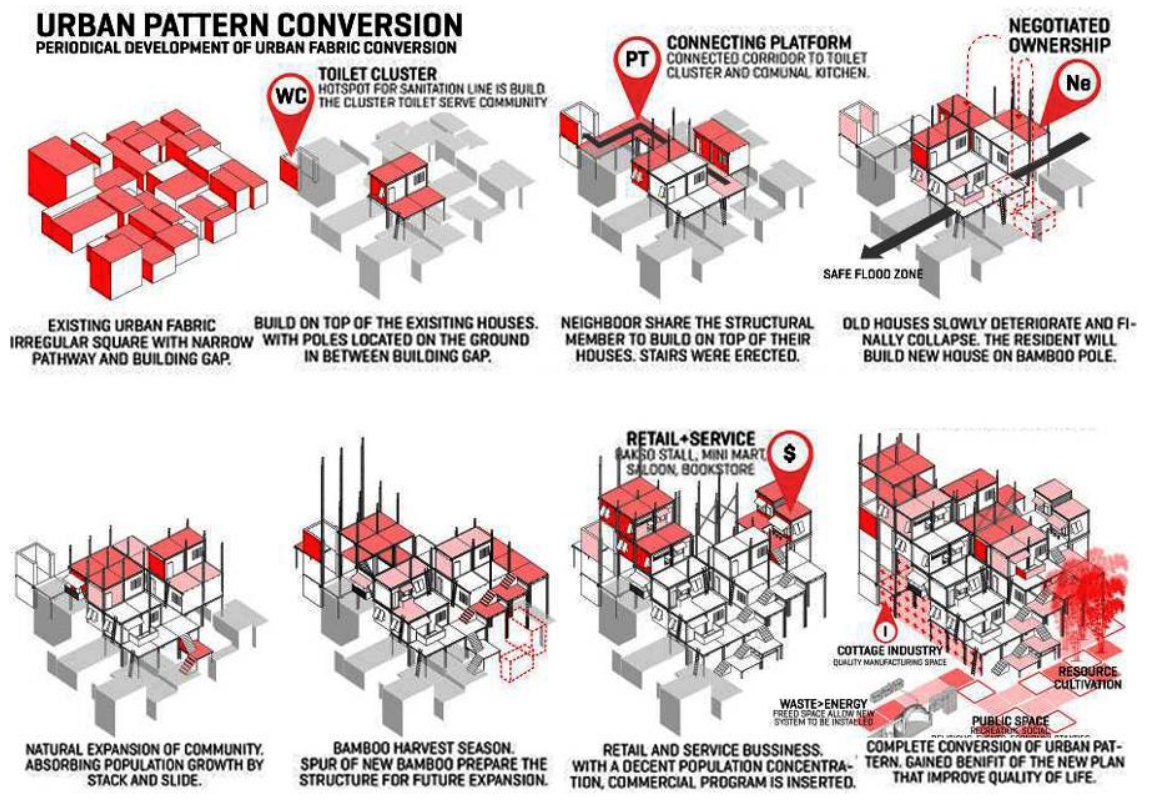

Figure 6: Urban pattern conversion.

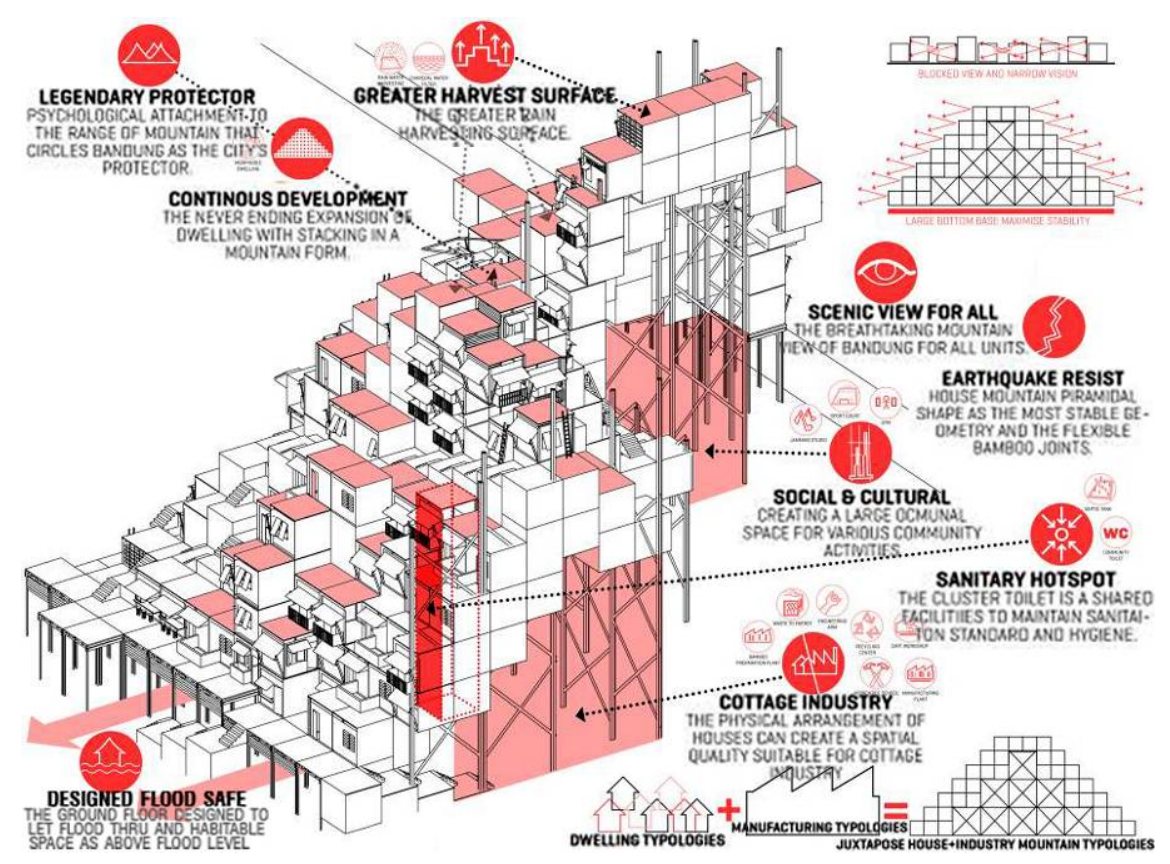

Figure 7: The mountain range section. 
The new housing system is built in a manner mimicking the mountains of Bandung. The new dwelling system development will surround the site mimicking the range of mountain that circles Bandung. The analogy of the mountain as a protector is used as an overall image of all the dwellings in the parameter of the site, which is how the mountain range becomes the mythical protector for Bandung, the dwelling also becomes the symbol of strength and protection for the villagers.

The community social block will be grouped in the same mountain cluster and will be named after the actual mountains that encircle Bandung. The mountain like dwelling shape creates an opportunistic urban consequences. The idea originated from the problem of spatial needs of the locals that need both dwelling space and factory space in a very limited land. The hybrid of factory typologies with the village dwelling created by the mountain like development, result in large multi volume voids under the houses. The bottom of the house is left empty and suitable for multiple manufacturing purposes that are currently run by residents in their small houses. Manufactured goods such as cloth, toys and souvenirs can be produced more efficiently at the new space below the house, increasing both production capacity and product quality. This economical benefit will influence the quality of life of the residents directly with revenue of the manufactured goods.

\section{Redefining tourism}

The city of Bandung claims to be enriched by grandeur, but in reality it is becoming a hapless imitation of European malls. This is a lifestyle fit for only a fraction of its population, with absolutely no significance to the majority of its indigenous local population. The city feeds on tourists, grasping each one of them for their money. Bandung's effort to become a tourist destination will never succeed as long as it is becoming a hypocrite to its own people. The need to redefine tourism is vital as it is the only way to save its pride and the future of its people.

A possible near future needs to be imagined for the ever growing city and how it would look like to symbolize a new era where tourists from all over the world are eager to come for its uniqueness and rarity. New programs that manifest themselves physically through innovative architectural intervention need to be created to reformulate the public realm and private domains of the city.

Slum tourism is a type of tourism that involves visiting impoverished areas, which has become increasingly prominent in several developing countries like India, Brazil, Kenya, and Indonesia. The rising phenomenon of slum tourism has western tourists paying to take guided tours of slums. Prior to the release of Slumdog Millionaire in 2008, this tourism niche is operating in almost all major slums around the world, including Jakarta. Critics say slum tourism, like poorism, is likened to a kind of voyeurism, exploiting people less fortunate, snapping pictures and leaving nothing in return. Therefore some tours do use portions of the profits to help out the villagers. This project will help raise 
awareness about slums and injustice in humanity. Tourists, both locally and internationally can experience firsthand the lives of the families living in these slumps. Proceeds from the tour will be donated to the residents. As the community upgrades itself culturally, economically and socially, the project would expand its tourism market, thus alleviating itself from the stigma of being a dejected slum.

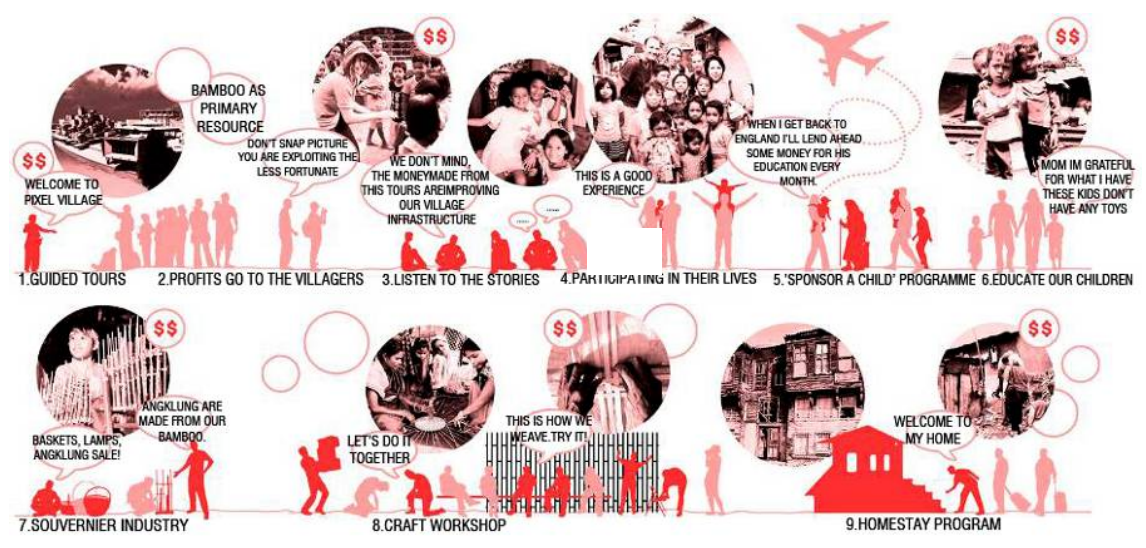

Figure 8: Slum tourism initiatives.

\section{Utilizing indigenous material: bamboo}

The use of bamboo within this community is not a new trait to the villagers. Bamboo can be seen growing in a few pockets within the site as it is endemic to this urban environment but yet it is not cultivated to its highest extend and only widely used as scaffolding. A total of eight different bamboo species originating from Indonesia have been selected to suit Bandung's unique climate.

Bamboo grows five times faster and it recycles 4 times the amount of carbon dioxide than the average timber as well as an excellent knot preventing soil erosion during floods. It is also proven to have twice the compressive strength of concrete and the same tensile strength of steel. Bamboo can be used in various stages of its lifetime for many different purposes.

\section{SELECTED BAMBOO SPECIES \\ ITS PROPERTIES AND APPLICATION}
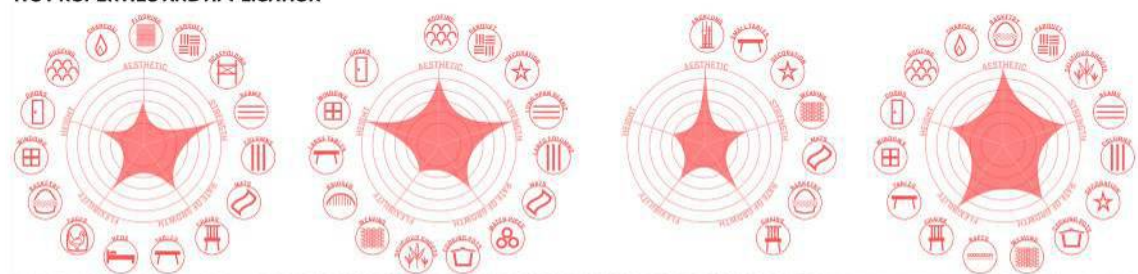

BAMBUSA BLUMEANA DENDROCAL AMUS ASPER GIGANTOCHLOA ATROVIOLACEA DENDROCALAMUS LATIFLORUS

Figure 9: Properties and uses of selected bamboo species. 


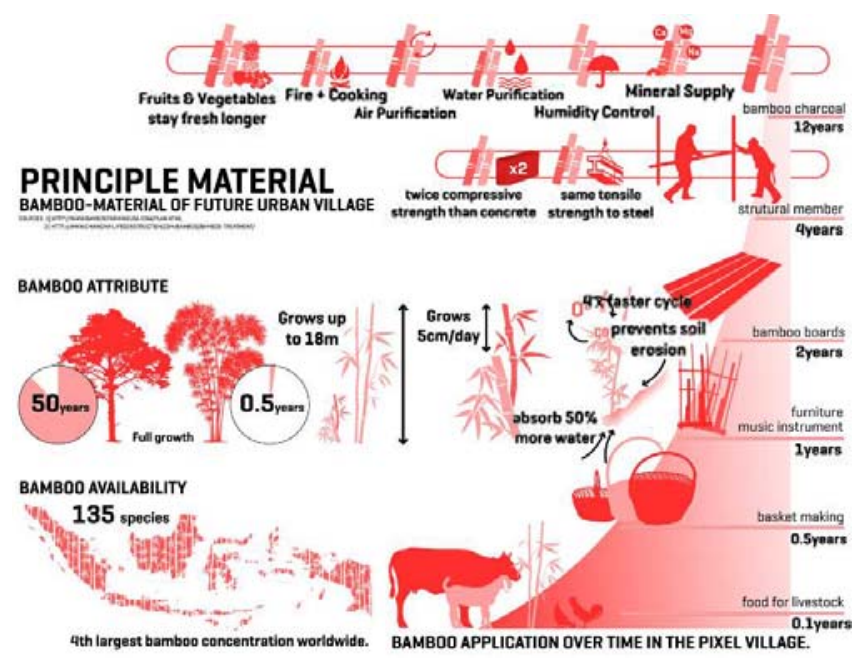

Figure 10: Bamboo as prime material.

\section{Urban Component Redevelopment}

The entire urban village rejuvenation project will be constructed within a period of 10 years whereby various implementation phases will be addressed to different community groups for legal and physical action to take place. Figure 11 illustrates a few improvements and post evaluation analysis of the overall outcome such as a $50 \%$ increase of personal space, $18 \%$ increase of open space and facilities, as well as a total of $7000 \mathrm{~km}$ of bamboo grown within the village in an accumulated 10 year period.

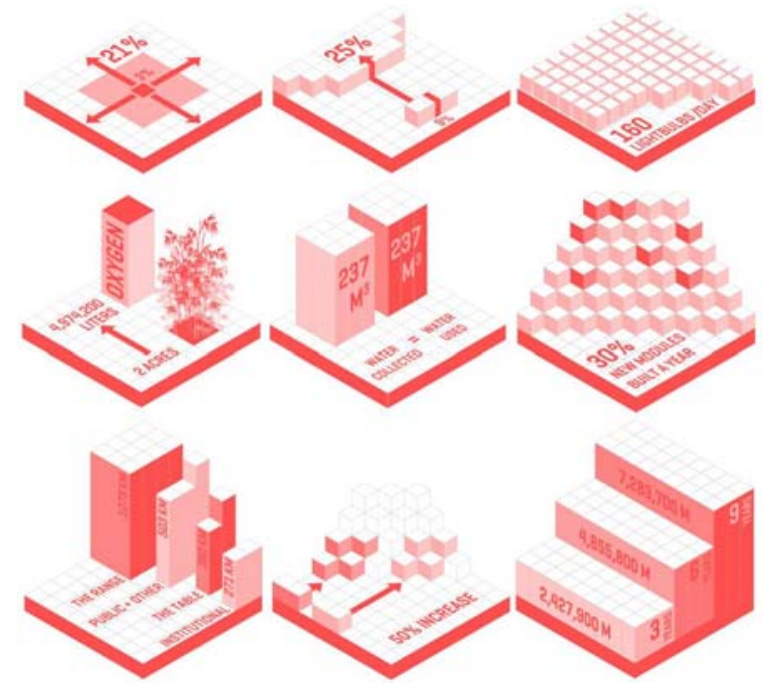

Figure 11: $\quad$ Dwelling performance. 


\section{Conclusion}

Urbanization formulation for villages to attain a liveable place that meet the diverse needs of the community, both now and in the future relate to the three major self-empowerment parameter framework. By reconfiguring urban space within these slums, villagers can move forward in various aspects of their daily live especially in terms of personal space, hygiene, and food security within their economical capacity.

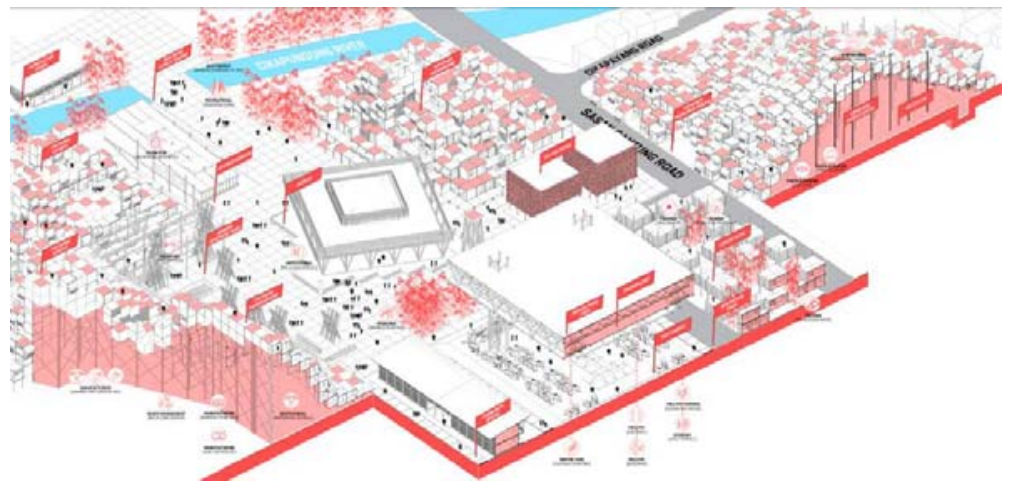

Figure 12: Program juxtaposition.

These successful urban settings will become places where villagers become safe and secure, thus providing a high quality of life for the people who live, work and play within these walls. A viable urban community can only be achieved when its people become the change they wish to see in their lifestyle.

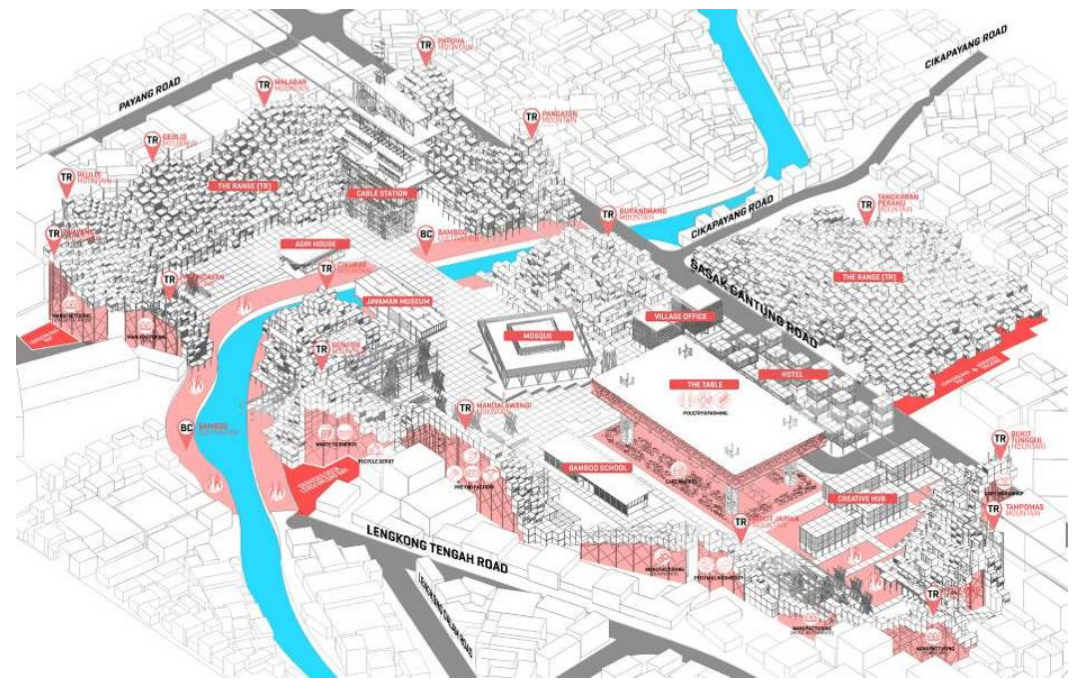

Figure 13: Arial view of Pixel Village. 


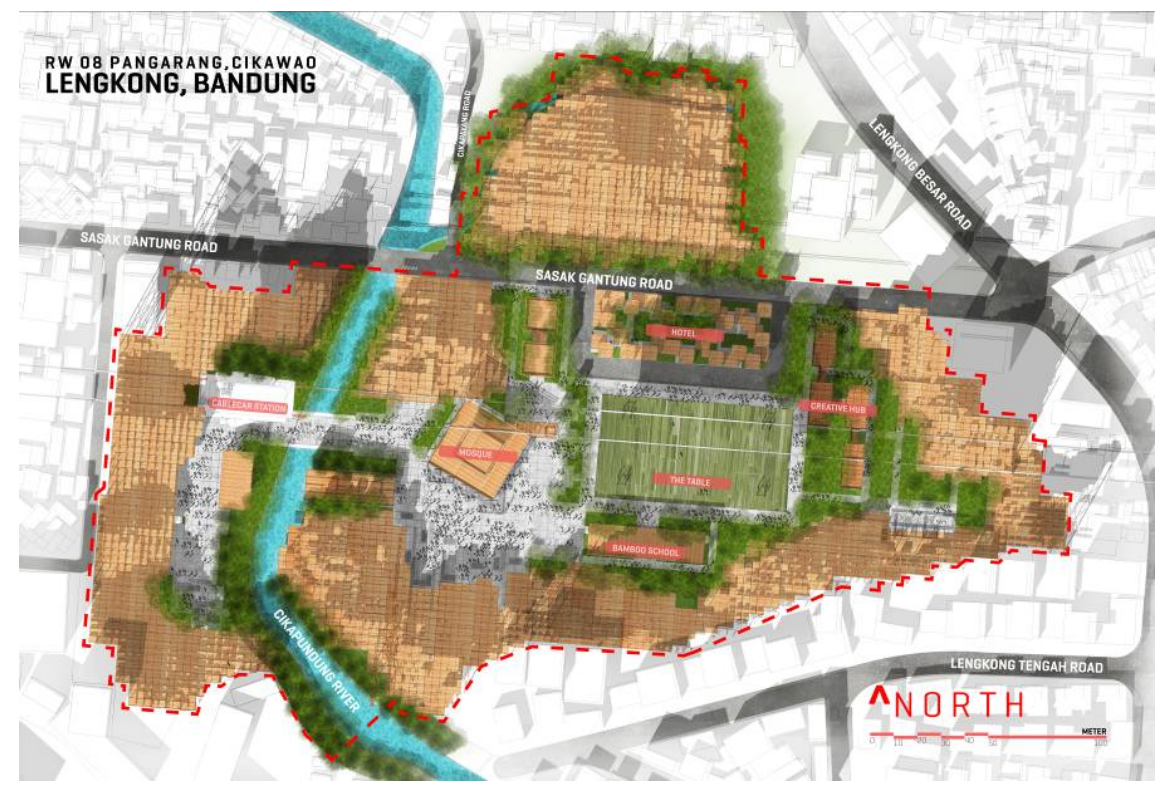

Figure 14: Pixel Village master plan.

\section{References}

[1] Siregar, S.A., Bandung - Architecture of A City in Development, Volume II Urban Analysis of a regional capital as a contribution to the present debate on Indonesian urbanity and architectural identity. Indonesia: UNPAR \& K.U.Leuven, 1990.

[2] Kortschak, Irfan, Invisible People-Poverty and Empowerment in Indonesia. Indonesia: Lontar Foundation for PNPM Support Facility, 2010.

[3] Tibaijuka, Anna K., The State of the World's Cities Report 2006/2007. UK: Earthscan UN-Habitat, 2007.

[4] PNPM Mandiri, Personnel Performance Evaluations of National Programs for Community Empowerment (PNPM) Rural, 2008.

[5] Mirza, Soraya, Strategic Urban Planning and Design Tools for Inner City Regeneration Towards a Strategic Approach of Sustainable Urban Form Future The Case of Bandung City. Indonesia, 2010.

[6] Cohen, Barney, Urban Growth in Developing Countries: A Review of Current Trends and a Caution Regarding Existing Forecasts, 2003. 